\title{
Preference of Fruit Flies, Bactrocera spp. in Relation to Size and Ripeness of Intact and Fallen Guava Fruits
}

\author{
S. Vignesh ${ }^{1 *}$ and M.Chandrasekaran ${ }^{2}$ \\ ${ }^{1}$ Anbil Dharmalingam Agricultural College and Research Institute \\ ${ }^{2}$ Horticultural College and Research Institute for Women \\ Tamil Nadu Agricultural University, Tiruchirappalli 620027 \\ Tamil Nadu, India \\ *Corresponding author
}

\section{Keywords}

Guava, Fruit fly, Bactrocera spp., Feeding preference, Fruit size and fruit ripeness

\section{Article Info}

Accepted:

20 May 2020

Available Online:

10 June 2020

\section{A B S T R A C T}

The productivity of the guava fruit is mainly ravaged by the fruit flies, Bactrocera spp. and found to be the major devastating insect pest that causes extensive damage. Fruit flies cause direct damage to fruit by oviposition punctures followed with the feeding of maggots. The greatest threat influenced by the fruit flies is the rejection of harvested fruits in markets and exporters especially in case of guava due to the presence of maggots, it leads fruit becoming unfit for marketing and consumption. To overcome this problem basic knowledge on the scientific reasons behind the preference towards the guava fruits exerted by the fruit flies to be ascertained. The ovipositional preference of the fruit flies may vary depends upon the fruit phenology viz., size, ripeness, odor and thickness of pericarp etc., Thus, the present investigation on preference of fruit flies in relation to fruit size and ripeness in guava was carried out by sampling and assessment of maggot population, pupal percentage, adult emergence and sex ratio in intact and fallen fruits. The overall sampling study revealed that the maggot population was more in large sized fruits i.e., $30-50$ per fruit in fallen condition and $20-30$ in intact fruits and the adult emergence was also more in the large sized fruits ( $>70 \%$ ) when compared with the small and medium sized fruits. Comparing the intact and fallen fruits, the fallen fruit shows the higher population (41.67/fruit) and intact fruits shown comparatively less population (24.75/fruit). The infestation of B. caryeae was higher than the B.dorsalis and sex ratio recorded shows the male population is more in B.dorsalis whereas the male and female seems to be present in equal ratio in case of $B$. caryeae.

\section{Introduction}

Guava (Psidium guajava Linn.) is one of the most important fruit crop belonging to the family Myrtaceae and popularly it is known as "Poor man's apple" or "Apple of tropics". It is native to Central America and introduced into India by Portuguese during the $17^{\text {th }}$ century (Baloda et al., 2018). It is rich in protein, vitamin $\mathrm{C}$, ascorbic acid, calcium, 
iron and phosphorus. The guava fruit is normally used in table purpose as well as in preservation industry for making jam, jelly and other value added products. Guava tree is well suited for cultivation under tropical and subtropical climatic conditions. It is capable of withstanding adverse situation in various types of soil (Gurjar et al., 2018). In India, the total area under guava is 2.6 lakhs ha with the annual production of 3.9 million tons and contributes about 4.0 percent of total fruit production. While comparing the productivity of guava with other nations, our country is poor in productivity due to the several insect pest problems (Jalaluddin, 2001). Guava crop is attacked by nearly 80 species of insect and mite pests, however only few of them have been noted as regular pest and causing serious damage. The most severe insect pest which attacking guava is fruit flies, Bactrocera spp., and potent enough to cause 60 to $80 \%$ damage (Jalaluddin et al., 1999). Fruit flies are polyphagous insect pest and strong fliers which is capable of flight up to two kilometers for searching food (Butani, 1974). Fruit flies cause direct damage to fruit by oviposition punctures on the fruit skin, through which saprophytic microbes invade into the fruit, resulting in rotting of the fleshy tissues. After the hatching of eggs, the maggots start feeding on the flesh, which hasten the fruit decay, resulting in unsuitability of fruits for human consumption. Severely infested fruits fall on the ground just prior to the pupation of maggots. Besides the direct damage, it will also cause indirect damage by affecting the export of fruit and brings a drastic loss in the country's economy (Heather and Hallman, 2008).India has been shortlisted in the countries from where import of fruits to developed countries is banned (Stone House et al., 2002).Fruit fly is a potential threat in successive production and marketing of guava, so it is mandatory to take necessary investigations on its preference in relation to size and ripeness of guava fruits to plan and frame out the timely management strategies in orchards for maximizing the profit.

\section{Materials and Methods}

The current investigation on the preference of fruit flies, Bactrocera spp. in relation to size and ripeness of intact and fallen guava fruitswas carried out in the entomology laboratory of Anbil Dharmalingam Agricultural College and Research Institute, Tiruchirappalli under normal room temperature $27 \pm 1^{0} \mathrm{C}$ by keeping the small, medium and large sized infested intact and fallen fruits separately in rearing cages to access the population built up in each categories of fruits.

Fruit flies lay their eggs on guava fruits in partially ripened stage. On hatching, the maggots enter into endocarp portion and start to feed fruit pulp. In the intact and fallen fruits presence of tiny punctures on the surface indicates the infestation of fruit flies. To understand the prevalence of fruit flies in the confined ecosystem the infested fruits were collected both from tree and ground based on the ovipositional puncture marks and brought into the laboratory and incubated at ambient temperature condition for adult emergence.

For the experiment, four guava trees enriched with blossoms and bearings were selected and tagged, from these trees both the intact and fallen infested fruits of three types viz., Small $(\leq 20 \mathrm{~cm}$ diameter $)$, Medium $(\leq 25 \mathrm{~cm}$ diameter) and Large fruits ( $\geq 30 \mathrm{~cm}$ diameter) were taken and placed in a plastic container of dimension $10 \times 8 \times 15 \mathrm{~cm}$ (lbh), covered with the net by following the procedure of Jadhav and Patil (2013).

The plastic container is filled with the sterilized sand up to a depth of $3 \mathrm{~cm}$ which 
serves as the media for pupation, the container with infested fruit is incubated at 27 $\pm 1^{0} \mathrm{C}$ and $75 \pm 2 \% \mathrm{RH}$ for the period of 21 days. The pupae in the sand were sieved and collected carefully, the pupae collected from the sand were transferred into a rearing cage of dimension 35 X 35 X $30 \mathrm{~cm}$ (lbh) and kept undisturbed for the adult emergence.

The emerged young ones were fed with yeast, sugar and honey solution on a cotton swab, additionally water is provided for the adult development (Kamala et al.,2017).

During the study, number of puparia collected from the fruit, percentage of adult emergence, sex ratio, parasitoid emergence were recorded and the species of emerged fruit flies were taxonomically identified by running the keys of David and Ramani (2011). The observed parameters on the number of maggots, per cent pupation, adult emergence and sex ratio were taken to assess its preference towards size and ripeness in fallen and intact guava fruits.

\section{Results and Discussion}

The previous reports on the seasonal occurrence and the activity of fruit flies indicated that, the prevalence of Bactrocera spp. in guava orchards was peak in abundance during the months of March and April; moreover the population abundance was also positively correlated with the maximum temperature (Das et al., 2017).

The flowering to fruiting stage of guava was also coincides in this period with the availability of intact and fallen fruits in tropical regions. Keeping this in mind, the present study on the assessment of the preference of intact and fallen guava fruits to the fruit fly, Bactrocera spp. was carried out from January to May month.

\section{Preference exerted by the fruit fly species} Bactrocera spp.

The assessment on the preference of fruit fly species complex in guava ecosystem showed the presence and spread of Bactrocera spp. in guava orchards during the experimental period. The identification of trapped fruit flies at species level by using taxonomic keys clearly indicated that the population of B.dorsalis and B.correcta were more prevalent both in intact and fallen guava fruits, the occurrence and preference of these two species in mixed fruit ecosystem is also reported by Taylor et al., (2005) in Tamil Nadu, Bheemanna and Prabhuraj (2017) in Karnataka and David et al., (2016) in Andaman Nicobar islands. The record on the presence of these two species and its high preference of guava fruits is accordance with the results on the high response of these two species towards guava orchards of Punjab region (Balaji and Singh, 2018).

The ovipositional preference of fruit flies in different sized fruits were examined by sampling infested guava fruits both in intact and fallen condition, the results shows that more number of maggots were recorded in the large sized fruits $(30.50-41.67 /$ fruit $)$ and maximum adult emergence $(62.25-91.99 \%)$ was also noted in the large sized fruits when compared with the medium and small sized fruits. The influence of large sized fruits with increased oviposition was found to be in consonance with the findings of Malheiro et al., (2015), who stated that bigger sized fruits were preferred by olive fruit flies than the smaller fruits at Mexico and Kamala Jayanthi et al., (2017) in oriental fruit fly. The combining effect of visual and olfactory stimuli will enhance the fruit fly catch in guava orchards; this concept is in tune with the reports of Alyokhin et al., (2000) in oriental fruit flies. 


\section{Maggot population}

The observations illustrated in Table1and 2, clearly depicts the range of Bactrocera spp. infestation that the maggot population was more in the large sized fruits both in intact and fallen condition and it was followed by the medium and small sized fruits. The high preference of fallen guava fruits by Bactrocera spp. was proved with the registered maggot's population that the number of maggots was more in fallen fruits (18.75 - 41.67), when compared with the intact fruits $(6.75-24.75)$. The maximum number of maggots of $B$. correcta (41.67) and $B$. dorsalis (39.00) was noted in the month of January in fallen guava fruits, it was 24.75 and 22.75 in intact fruits in the month of April. The population trend of maggots and adult emergence pattern of $B$. dorsalis and $B$. correcta were represented in Fig.1 and Fig.2 respectively. Irrespective of species, the incidence and multiplication of fruit flies was more in fallen fruits than in intact fruits, moreover the maximum incidence (up to $50 \%$ ) and population was started in the month of January itself in fallen fruits but it was comparatively less $(<25 \%)$ in intact fruits. The larval survival is highly favoured by the ripen fruits and confirms the firmness of fruit is the major factor that influences the infestation. Díaz-fleischer and Aluja (2003) also opinioned that the soft and ripen fruits were highly preferred by Anastrapha ludens in a confined mango ecosystem. Considering the impact of size, the small size intact fruit the maggot population was very minimum $(<$ 10 per fruit) but it was $>20$ per fruit in fallen fruits. The preference was logically increased towards the medium and large sized fruits. In case of medium sized fruits the maximum of 18.25 maggots were recorded in intact, but it was 25.75 per fruit in fallen fruits. The proneness of large size fruits was strengthened by the data registered with more than 30 maggots per fallen fruit and the maximum of 24.75 maggots per intact fruit was observed throughout the experimental period. The thickness of the rind, gradual increase in ripeness and the changing of the color from green to yellow during ripening might be the possible reasons for the exertion of preference towards ripened large sized fallen fruits than the intact fruits. The role and response of visual stimuli towards the attraction and preference of fruit flies to the yellow color observed in this study is well strengthened by the findings of Cornelius et al., (1999) in female oriental fruit flies to fruit-mimicking traps.

\section{Fruit fly Pupation and Adult emergence}

The results obtained on the per cent pupation and adult emergence of Bactrocera spp. both in fallen and intact fruits conveyed that the size and ripeness of the fruits were almost non significant in registering the variation both in fallen and intact fruits. The intactness of the fruit in tree and the fallen fruits in the ground canopy of the tree both are registered the per cent pupation (64.91 - 91.86) and the adult emergence (61.88 - 92.28) of fruit flies, irrespective of species. These results obtained on the per cent pupation and adult emergence clearly indicated that the size, stage (intact and fallen) and ripeness of guava fruits were does not show any influence on pupation of fruit fly maggots.

The overall observation parameters concluded that though there is non significance in the variation, the maximum per cent in pupation and adult emergence was noticed in fallen fruits when compared with the intact fruits. These findings concluded that semi to full ripeness, partial decaying and delayed rottenness of the fallen fruits may provide a congenial condition for the better pupation and adult emergence. Considering the sex ratio, the overall observation shows the male population of B.dorsalis was more when compared with the females, whereas male and female seems to be equal in $B$. caryeae. 
Table.1 Preference of $B$. dorsalis in relation to fruit size and ripeness of intact and fallen guava fruits

\begin{tabular}{|c|c|c|c|c|c|c|c|c|c|c|c|c|}
\hline \multicolumn{13}{|c|}{ Fallen fruits* } \\
\hline \multirow[t]{2}{*}{2018} & \multicolumn{4}{|c|}{ Small } & \multicolumn{4}{|c|}{ Medium } & \multicolumn{4}{|c|}{ Large } \\
\hline & $\begin{array}{c}\text { No. of } \\
\text { Maggots }\end{array}$ & $\begin{array}{c}\text { Pupation } \\
(\%)\end{array}$ & $\begin{array}{c}\text { Adult } \\
\text { emergence } \\
(\%)\end{array}$ & $\begin{array}{l}\text { Sex } \\
\text { ratio } \\
M: F\end{array}$ & $\begin{array}{c}\text { No. of } \\
\text { Maggots }\end{array}$ & $\begin{array}{c}\text { Pupation } \\
(\%)\end{array}$ & $\begin{array}{c}\text { Adult } \\
\text { emergence } \\
(\%)\end{array}$ & $\begin{array}{c}\text { Sex } \\
\text { ratio } \\
\text { M:F }\end{array}$ & $\begin{array}{c}\text { No. of } \\
\text { Maggots }\end{array}$ & $\begin{array}{c}\text { Pupation } \\
(\%)\end{array}$ & $\begin{array}{c}\text { Adult } \\
\text { emergence } \\
(\%)\end{array}$ & $\begin{array}{l}\text { Sex } \\
\text { ratio } \\
\text { M:F }\end{array}$ \\
\hline Jan & 20.67 & 85.26 & 72.65 & 0.9:1.0 & 25.33 & 77.56 & 83.87 & $1.0: 1.0$ & 39.00 & 75.36 & 73.58 & $0.9: 1.0$ \\
\hline Feb & 20.33 & 74.71 & 75.14 & 1.0:0.9 & 24.25 & 82.11 & 90.97 & $1.0: 0.9$ & 31.25 & 78.10 & 76.35 & $1.0: 1.0$ \\
\hline Mar & 22.00 & 75.42 & 77.60 & 1.0:1.0 & 25.25 & 73.82 & 74.42 & $1.0: 0.8$ & 36.25 & 72.63 & 74.09 & $1.0: 0.7$ \\
\hline April & 18.75 & 65.81 & 76.67 & 1.0:0.9 & 30.75 & 73.82 & 73.20 & $1.0: 0.9$ & 30.75 & 71.31 & 73.91 & $1.0: 1.0$ \\
\hline \multicolumn{13}{|c|}{ Intact fruits* } \\
\hline \multirow[t]{2}{*}{2018} & \multicolumn{4}{|c|}{ Small } & \multicolumn{4}{|c|}{ Medium } & \multicolumn{4}{|c|}{ Large } \\
\hline & $\begin{array}{c}\text { No. of } \\
\text { Maggots }\end{array}$ & $\begin{array}{c}\text { Pupation } \\
(\%)\end{array}$ & $\begin{array}{c}\text { Adult } \\
\text { emergence } \\
(\%)\end{array}$ & $\begin{array}{l}\text { Sex } \\
\text { ratio } \\
\text { M:F }\end{array}$ & $\begin{array}{c}\text { No. of } \\
\text { Maggots }\end{array}$ & $\begin{array}{c}\text { Pupation } \\
(\%)\end{array}$ & $\begin{array}{c}\text { Adult } \\
\text { emergence } \\
(\%)\end{array}$ & $\begin{array}{l}\text { Sex } \\
\text { ratio } \\
\text { M:F }\end{array}$ & $\begin{array}{c}\text { No. of } \\
\text { Maggots }\end{array}$ & $\begin{array}{c}\text { Pupation } \\
(\%)\end{array}$ & $\begin{array}{c}\text { Adult } \\
\text { emergence } \\
(\%)\end{array}$ & $\begin{array}{l}\text { Sex } \\
\text { ratio } \\
\text { M:F }\end{array}$ \\
\hline Jan & 7.00 & 90.80 & 79.76 & $0.7: 1.0$ & 14.67 & 90.00 & 72.20 & $1.0: 0.9$ & 22.33 & 79.53 & 83.29 & $1.0: 1.0$ \\
\hline Feb & 15.67 & 83.89 & 71.04 & 1.0:0.9 & 17.25 & 81.15 & 77.68 & 1.0:0.9 & 21.50 & 76.68 & 91.99 & $1.0: 0.9$ \\
\hline Mar & 6.75 & 81.01 & 57.71 & 1.0:1.0 & 14.75 & 69.49 & 79.17 & $0.9: 1.0$ & 22.25 & 79.46 & 82.35 & $1.0: 0.9$ \\
\hline April & 9.25 & 86.01 & 67.63 & $0.7: 1.0$ & 15.75 & 76.19 & 68.39 & $0.8: 1.0$ & 22.75 & 79.04 & 81.74 & $1.0: 0.9$ \\
\hline
\end{tabular}

*Mean value of four replications 
Table. 2 Preference of B. correcta in relation to fruit size and ripeness of intact and fallen guava fruits

\begin{tabular}{|c|c|c|c|c|c|c|c|c|c|c|c|c|}
\hline \multicolumn{13}{|c|}{ Fallen fruits* } \\
\hline \multirow[t]{2}{*}{2018} & \multicolumn{4}{|c|}{ Small } & \multicolumn{4}{|c|}{ Medium } & \multicolumn{4}{|c|}{ Large } \\
\hline & $\begin{array}{c}\text { No. of } \\
\text { Maggots }\end{array}$ & $\begin{array}{c}\text { Pupation } \\
(\%)\end{array}$ & $\begin{array}{c}\text { Adult } \\
\text { emergence } \\
(\%)\end{array}$ & $\begin{array}{c}\text { Sex } \\
\text { ratio } \\
M: F\end{array}$ & $\begin{array}{c}\text { No. of } \\
\text { Maggots }\end{array}$ & $\begin{array}{c}\text { Pupation } \\
(\%)\end{array}$ & $\begin{array}{c}\text { Adult } \\
\text { emergence } \\
(\%)\end{array}$ & $\begin{array}{l}\text { Sex } \\
\text { ratio } \\
\text { M:F }\end{array}$ & $\begin{array}{c}\text { No. of } \\
\text { Maggots }\end{array}$ & $\begin{array}{c}\text { Pupation } \\
(\%)\end{array}$ & $\begin{array}{c}\text { Adult } \\
\text { emergence } \\
(\%)\end{array}$ & $\begin{array}{c}\text { Sex } \\
\text { ratio } \\
M: F\end{array}$ \\
\hline Jan & 21.00 & 81.51 & 75.63 & $0.9: 1.0$ & 23.67 & 85.03 & 82.29 & 1.0:0.6 & 41.67 & 76.90 & 72.53 & $0.9: 1.0$ \\
\hline Feb & 21.67 & 75.07 & 81.83 & $1.0: 0.8$ & 25.75 & 91.86 & 75.71 & 1.0:0.8 & 30.50 & 86.74 & 69.99 & $0.9: 1.0$ \\
\hline Mar & 20.50 & 72.57 & 92.28 & $1.0: 0.9$ & 24.00 & 86.94 & 70.63 & $1.0: 0.8$ & 34.50 & 79.06 & 71.06 & $0.9: 1.0$ \\
\hline April & 19.75 & 82.90 & 59.16 & $0.8: 1.0$ & 29.50 & 86.94 & 64.52 & 1.0:0.9 & 34.75 & 75.16 & 62.25 & $1.0: 0.6$ \\
\hline \multicolumn{13}{|c|}{ Intact fruits* } \\
\hline \multirow[t]{2}{*}{2018} & \multicolumn{4}{|c|}{ Small } & \multicolumn{4}{|c|}{ Medium } & \multicolumn{4}{|c|}{ Large } \\
\hline & $\begin{array}{c}\text { No. of } \\
\text { Maggots }\end{array}$ & $\begin{array}{c}\text { Pupation } \\
(\%)\end{array}$ & $\begin{array}{c}\text { Adult } \\
\text { emergence } \\
(\%)\end{array}$ & $\begin{array}{c}\text { Sex } \\
\text { ratio } \\
M: F\end{array}$ & $\begin{array}{c}\text { No. of } \\
\text { Maggots }\end{array}$ & $\begin{array}{c}\text { Pupation } \\
(\%)\end{array}$ & $\begin{array}{c}\text { Adult } \\
\text { emergence } \\
(\%)\end{array}$ & $\begin{array}{c}\text { Sex } \\
\text { ratio } \\
\text { M:F }\end{array}$ & $\begin{array}{c}\text { No. of } \\
\text { Maggots }\end{array}$ & $\begin{array}{c}\text { Pupation } \\
(\%)\end{array}$ & $\begin{array}{c}\text { Adult } \\
\text { emergence } \\
(\%)\end{array}$ & $\begin{array}{c}\text { Sex } \\
\text { ratio } \\
M: F\end{array}$ \\
\hline Jan & 9.33 & 63.88 & 85.32 & $1.0: 1.0$ & 15.33 & 75.00 & 75.27 & 1.0:1.0 & 23.67 & 81.40 & 85.97 & $1.0: 1.0$ \\
\hline Feb & 17.33 & 82.58 & 73.82 & $0.7: 1.0$ & 18.25 & 86.30 & 80.60 & $0.7: 1.0$ & 22.75 & 84.93 & 77.50 & $1.0: 1.0$ \\
\hline Mar & 8.50 & 64.91 & 61.88 & $0.9: 1.0$ & 15.75 & 71.42 & 81.38 & 1.0:0.9 & 24.50 & 86.46 & 89.19 & $1.0: 1.0$ \\
\hline April & 10.25 & 79.20 & 73.88 & $1.0: 0.7$ & 16.50 & 78.78 & 84.02 & $1.0: 1.0$ & 24.75 & 84.38 & 85.49 & $0.9: 1.0$ \\
\hline
\end{tabular}

\footnotetext{
*Mean value of four replications
} 
Fig.1 Preference of Bactrocera dorsalis in intact and fallen guava fruits

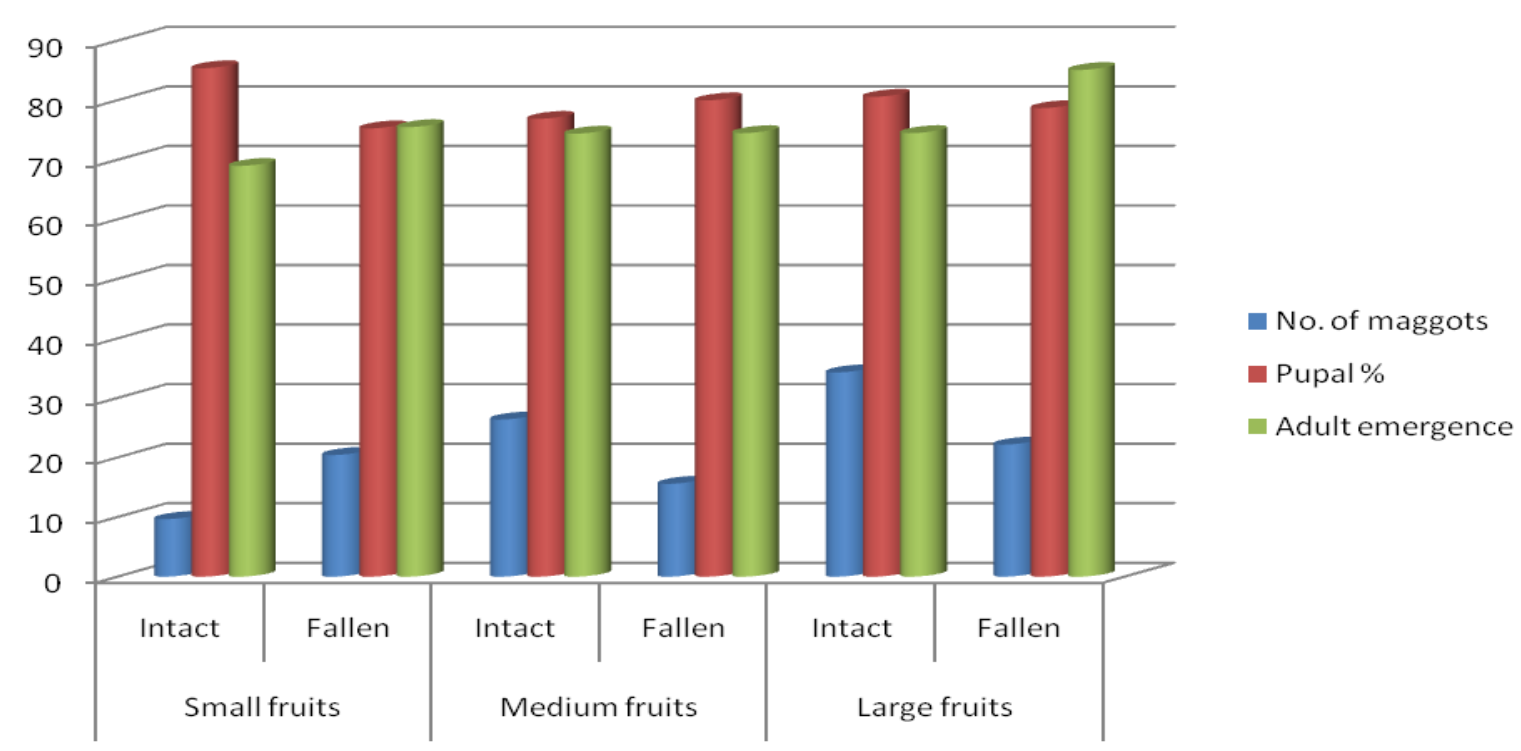

Fig.2 Preference of Bactrocera correcta in intact and fallen guava fruits

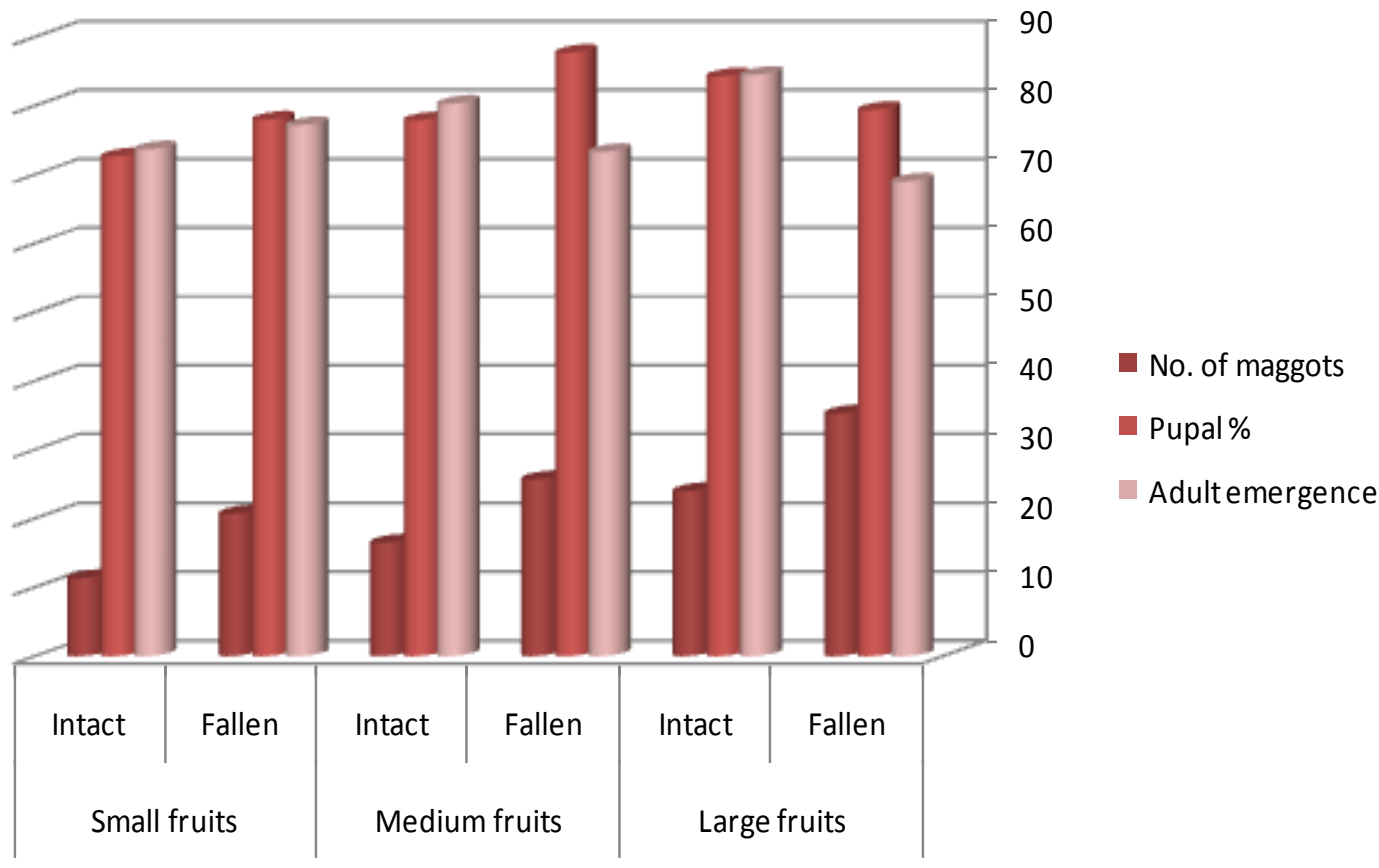


The present findings of the proneness of large sized fallen guava fruits to the attack of fruit flies was well strengthened by the reports of Rizzo and Caleca (2006), according to their results the correlation shown that the response of maximum population of fruit flies with increased fruit size. The findings of Migani (2013) shown that the physiological stage of the mango and its clutch size determines the fecundity of fruit flies, the fully ripened and semi ripened fruits shown the more probability for oviposition. It was in accordance with the current result, that the maximum load of fruit fly maggot in the large sized fruits. The influence of fruit stage in ovipositional preference was also strengthened by the findings of Rattanapun et $a l$. , (2009), in which he states that the pericarp toughness and total soluble sugars present in the different phenological stage of the fruit act as cues in attracting fruit flies. The influence of physico-chemical properties of various stages of fruits might be the major reason for the variation on its preference, it was in tune with the findings of Dhillion et al., (2005) in bitter gourd on larval density and resistance to melon fruit fly, B. cucurbitae (Coquillett).

The intact fruit was mostly in green and turning stage whereas the fallen fruits were mostly in turning yellow and ripe stage, the preference of fruit flies towards the large sized ripened fallen fruit sample conveys that the thinness of the fruit rind might be the reason to influence the oviposition. This experimental result was supported by the preference of fruit flies towards ripe stage of tomato and guava as reported by Balagawi et al., (2005) and Devi and Jha (2017), respectively.

The fruit in green stage i.e., before July shows the less pattern of incidence and from July onwards the fruits in green stage changes into turning stage were the incidence tends to be increased, this opinion and less preference of intact quality fruits than fallen semi-ripened fruits by Bactrocera spp. was also documented by Jadhav and Patil (2013) with their fruit quality management system based on image processing technologies.

In conclusion, the egg laying and feeding injury of fruit flies in guava is highly influenced by the size and ripeness of the intact and fallen fruits. Evidencing the preference of fruit flies towards various fruit size in intact and fallen condition may act as a valid tool in population assessment, distribution and per cent infestation.

The present finding revealed that the large sized fruits are more preferable than the medium and small sized fruits, whereas the fallen fruits recorded the maximum maggots built up when compared with intact fruits. So, hereby we conclude that picking up of intact medium sized guava fruits before falling over the ground due to over size and ripeness for marketing is better to escape from the loss inflicted by fruit flies. This valid information will be useful to the farmers to avoid the infestation of fruit flies by timely harvest of marketable fruits.

\section{Acknowledgement}

The corresponding author is greatly thankful to the Dean, Anbil Dharmalingam Agricultural College and Research Institute, TNAU, Tiruchirappalli, for providing the laboratory facilities to take up the experiments the Dean, Horticultural College and Research Institute for women, TNAU, Tiruchirappalli, for issuing the permission to take up the field experiment in mango orchard and the Dean, Horticultural College and Research Institute for women, TNAU, Tiruchirappalli, for issuing the permission to take up the field experiment in mango orchard. 


\section{References}

Alyokhin, A., Messing, V., and Duan J.J. 2000. Visual and olfactory stimuli and fruit maturity affect trap captures of oriental fruit flies (Diptera: Tephritidae). J. of Economic Entomology, 93(3): 644-649.

Balagawi, S., Vijaysegaran, S., Drew, R.A., and Raghu, S. 2005. Influence of fruit traits on oviposition preference and offspring performance of Bactrocera tryoni (Froggatt) (Diptera: Tephritidae) on three tomato (Lycopersicon lycopersicum) cultivars. Australian Journal of Entomology, 44(2): 97-103.

Balaji, K., and Singh, S. 2018. Response of fruit flies, Bactrocera spp.(Diptera: Tephritidae) to different shapes of methyl eugenol based traps in guava orchards of punjab, Journal of entomology and zoology studies, 6(2): 2435-2438.

Baloda, S., Sharma, J.R., Kumar, M., Singh, S., and Malik, A. 2018. Studies on the performance of rejuvenated plants and fresh plants of guava. Ind. J. Pure and App. Biosci.,6(1): 939-941.

Bheemanna, M., and Prabhuraj, A. 2017. Diversity of fruit flies in different agroclimatic zones of Karnataka, Journal of entomology and zoology studies, 5(6): 1163-1167.

Butani, M., 1974. Insect pest of fruit crops and their control. Periodical Export Book Agency.Pp.12-21.

Cornelius, M. L., Duan, J.J., and. Messing, R.H., 1999. Visual stimuli and the response of female oriental fruit flies (Diptera: Tephritidae) to fruitmimicking traps. J. of Economic Entomology, 92(1): 121-129.

Das, U., Okram, S., and Jha, S.K.K.S. 2017. Species diversity and monitoring of population dynamics of two species of Bactrocera (B. dorsalis, B. zonata) through methyl eugenol traps at lower gangetic alluvium of West Bengal. Journal of Entomology and Zoology Studies, 5(4):372-376.

David, K.J., and Ramani, S., 2011. An illustrated key to fruit flies (Diptera: Tephritidae) from Peninsular India and the Andaman and Nicobar islands. Zootaxa, 3021(1): 1-31.

David, K.J., Ramani,S., Whitmore, D., and Ranganath, H.R. 2016. Two new species and a new record of Bactrocera macquart (Diptera: Tephritidae: Dacinae: Dacini) from India. Zootaxa, 4103(1): 25-34.

Devi, R., and Jha, S. 2017. Oviposition tendency of Bactrocera dorsalis (Diptera: Tephritidae) infesting guava (Psidium guajava L.) in relation to fruit ripening stages, Journal of entomology and zoology studies, 5(4): 1869-1875.

Dhillon, M.K., Naresh, J.S., Singh, R., Sharma, N.K. 2005. Influence of physic-chemical traits of bitter gourd, Momordica charantia L. on larval density and resistance to melon fruit fly, Bactrocera cucurbitae (Coquillett). Journal of applied Entomology, 129: 393-399.

Díaz-fleischer, F., and Aluja, M., 2003. Clutch size in frugivorous insects as a function of host firmness: the case of the tephritid fly, Anastrepha ludens. Ecological Entomology, 28(3): 268277.

Gurjar, S., Singh, P.K., Lal, S., Kushwahan, R., Jitendra Singh, Lekhi, R., and Singh, M. 2018. Evaluation of guava (Psidium guajava L.) varieties under arid zone of Madhya Pradesh. Ind. J. Pure and App. Biosci., 6(1): 174-177.

Heather, N.W., and Hallman, G.J. 2008.Pest Management and Phytosanitory Trade Barriers. CABI, Wallingford, Cambridge, United Kingdom.

Jadhav and Patil. 2013. A fruit quality 
management system based on image processing. IOSR Journal of electronics and communication engineering (iosrjece), 8(6): 01-05.

Jalaluddin, S., 2001. An overview of fruit fly research knowledge and needs in the Indian Ocean region. In: Second National Symposium on Integrated Pest Management (IPM) in Horticultural Crops, P. 21-23.

Jalaluddin, S., Natrajan, S., Sadakathulla, S., and Balasubramaniam, S. 1999. Discovery of the guava fruit fly, Bactrocera correcta. Entomon., 24(2): 195-196.

Kamala Jayanthi, P. D., Kempraj, V. and Bruce, J.A. 2017. Evaluation of synthetic oviposition stimulants to enhance egg collection of the oriental fruit fly, Bactrocera dorsalis (Diptera: Tephritidae). J. of Pest Science, 90(3): 781-786.

Malheiro, R., Casa, S., Baptista, P., and Pereira, J. 2015. A review of Bactrocera oleae (Rossi) impact in olive products: from the tree to the table. Trends in Food Science and Technology, 44(2): 226-242.
Migani, V., Ekesi, S., and Hoffmeister, T. 2014. Physiology Vs. environment: what drives oviposition decisions in mango fruit flies (Bactrocera invadens and Ceratitis cosyra), Journal of Applied Entomology, 138 (6): 395-402.

Rattanapun, W., Amornsak, W., and Clarke, A.R. 2009. Bactrocera dorsalis preference and performance on two mango varieties at three stages of ripeness. Entomologia experimental isapplicata, 131(3): 243-253.

Rizzo and Caleca. 2006. Resistance to the attack of Bactrocera oleae (Gmelin) of some sicilian olive cultivars. Olive bioteq, 6(2): 35-42.

Stonehouse, J.M., Madhura, H.S., Jayanthi, S., and Verghese, A. 2002. Fruit flies of economic significance in India, with special reference to Bactrocera dorsalis (Hendel). Proceedings of the 6th international fruit fly symposium May: 317-324.

Taylor, P., Agarwal, M.L., and Sueyoshi, M. 2005. Catalogue of Indian fruit flies (Diptera: Tephritidae). Zootaxa, 24(2): 37- 41.

\section{How to cite this article:}

Vignesh, S. and Chandrasekaran, M. 2020. Preference of Fruit Flies, Bactrocera spp. in Relation to Size and Ripeness of Intact and Fallen Guava Fruits. Int.J.Curr.Microbiol.App.Sci. 9(06): 2764-2773. doi: https://doi.org/10.20546/ijcmas.2020.906.335 